\title{
IMPLEMENTASI BADAN USAHA MILIK DESA (BUM DESA) DALAM PENGEMBANGAN EKONOMI MASYARAKAT
}

(Studi BUM Desa Petanahan Kecamatan Petanahan Kabupaten Kebumen)

\author{
Umi Arifah \\ Institut Agama Islam Nahdlatul Ulama (IAINU) Kebumen \\ umiarifah87@gmail.com
}

\begin{abstract}
ABSTRAK
Sebagai upaya mensejahterakan masyarakat dan memperkuat ekonomi masyarakat, Desa dapat mendirikan Badan Usaha Milik Desa (BUM Desa) sesuai dengan kebutuhan dan potensi Desa. BUM Desa ini merupakan badan usaha yang seluruh atau sebagian besar modalnya dimiliki oleh Desa melalui penyertaan modal secara langsung yang berasal dari kekayaan Desa yang dipisahkan guna mengelola aset, jasa pelayanan, dan usaha lainnya untuk sebesar-besarnya kesejahteraan rakyat. Dengan adanya BUM Desa diharapkan dapat mampu memberikan kontribusi yang signifikan terhadap pendapatan Desa untuk pembangunan Desa yang tujuan utamanya kesejahteraan masyarakat. Hasil penelitian menunjukkan BUM Desa Petanahan belum terlalu memberikan kontribusi terhadap peningkatan ekonomi masyarakat desa. Hal ini terjadi karena bidang usaha yang dilaksanakan BUM Desa Petanahan belum menyentuh masyarakat khususnya warga miskin dan dalam pelaksanaanya belum dilaksanakan secara partisipatif, transparan dan akuntabel.
\end{abstract}

Kata Kunci : Implementasi, Badan Usaha Milik Desa, Ekonomi Masyarakat

\section{PENDAHULUAN}

Pembangunan ekonomi desa merupakan subsistem dari pembangunan ekonomi kabupaten/kota, propinsi serta menopang ekonomi secara nasional. Desa sebagai pemerintahan terendah menjadi sandaran bagi kehidupan dan penghidupan warganya. Di desa juga banyak berkembang kearifan budaya, etika dan relasi sosial kemasyarakatan. Segala potensi sumber daya yang terdapat di desa tentunya dapat dikembangkan dengan tujuan kesejahteraan masyarakat.

Dalam mandat Undang-Undang Nomor 6 Tahun 2014 Tentang Desa tertuang dalam pasal 4 bahwa pengaturan desa bertujuan untuk memajukan 
perekonomian masyarakat desa serta mengatasi kesenjangan pembangunan nasional dan memperkuat masyarakat desa sebagai subjek pembangunan. Maka untuk mencapai tujuan tersebut dalam Undang-Undang tentang Desa memiliki ketentuan-ketentuan terkait Badan Usaha Milik Desa (BUM Desa). Badan Usaha Milik Desa (BUM Desa) adalah usaha desa yang dibentuk/didirikan oleh pemerintah desa yang kepemilikan modal dan pengelolaanya dilakukan oleh pemerintah desa dan masyarakat.

Pengaturan terkait BUM Desa yang tercantum dalam Undang-Undang Nomor 6 Tahun 2014 Tentang Desa kemudian diturunkan ke dalam Permendesa Nomor 4 Tahun 2015 Tentang Pendirian, Pengurusan dan Pengelolaan, dan Pembubaran Badan Usaha Milik Desa. Dalam Permendesa No. 4 Tahun 2015, sebagaimana disebutkan dalam pasal tiga, pendirian BUM Desa sendiri bertujuan:

a. Meningkatkan perekonomian desa;

b. Mengoptimalkan aset desa agar bermanfaat untuk kesejahteraan desa;

c. Meningkatkan usaha masyarakat dalam pengelolaan potensi ekonomi desa;

d. Mengembangkan rencana kerja sama usaha antar desa dan/atau dengan pihak ketiga;

e. Menciptakan peluang dan jaringan pasar yang mendukung kebutuhan layanan umum warga;

f. Membuka lapangan kerja;

g. Meningkatkan kesejahteraan masyarakat melalui perbaikan pelayanan umum, pertumbuhan dan pemerataan ekonomi desa; dan

h. Meningkatkan pendapatan masyarakat desa dan Pendapatan Asli Desa.

Tujuan-tujuan tersebut dengan jelas menyiratkan keinginan pemerintah untuk menjadikan BUM Desa sebagai ujung tombak upaya pemakmuran masyarakat desa. Melalui BUM Desa, pemerintah memberikan akses kepada masyarakat desa agar tidak terjebak pada sistem perekonomian subsisten dan dapat melibatkan diri dalam memaksimalkan potensi jaringan pasar, sehingga distribusi kapital yang selama ini terpusat pada daerah urban dapat lebih merata dan turut dirasakan oleh masyarakat yang berdomisili di pedesaan. 
Menurut Peraturan Menteri Dalam Negeri Nomor 39 Tahun 2010, jenisjenis usaha yang dapat diselenggarakan oleh BUM Desa meliputi: jasa; penyaluran sembako; perdagangan hasil pertanian, dan/atau industri kecil dan rumah tangga, dll.

Tabel 1 : Tipe Usaha Badan Usaha Milik Desa

\begin{tabular}{|c|c|c|}
\hline Tipe Usaha & Deskripsi & Contoh Unit Usaha \\
\hline $\begin{array}{l}\text { Serving/ } \\
\text { Jasa }\end{array}$ & $\begin{array}{l}\text { BUM Desa menjalankan } \\
\text { "bisnis sosial" yang melayani } \\
\text { warga, yakni dapat } \\
\text { melakukan pelayanan publik } \\
\text { kepada masyarakat. }\end{array}$ & $\begin{array}{l}\text { - Usaha air minum desa } \\
\text { - Usaha listrik desa (desa } \\
\text { mandiri energi) } \\
\text { - Jasa transportasi untuk warga } \\
\text { desa }\end{array}$ \\
\hline $\begin{array}{l}\text { Banking/ } \\
\text { Lembaga } \\
\text { Keuangan }\end{array}$ & $\begin{array}{l}\text { BUM Desa menjalankan } \\
\text { "bisnis uang" yang dapat } \\
\text { memenuhi kebutuhan } \\
\text { keuangan masyarakat desa } \\
\text { dengan bungan yang lebih } \\
\text { rendah daripada bunga yang } \\
\text { didapatkan masyarakat desa } \\
\text { dari para rentenir desa atau } \\
\text { bank-bank konvensional. }\end{array}$ & $\begin{array}{l}\text { - Lembaga keuangan mikro dan } \\
\text { usaha simpan pinjam untuk } \\
\text { mendukung kredit usaha }\end{array}$ \\
\hline $\begin{array}{l}\text { Brokering/ } \\
\text { Perantara }\end{array}$ & $\begin{array}{l}\text { BUM Desa dapat menjadi } \\
\text { "lembaga perantara" yang } \\
\text { menghubungkan komoditas } \\
\text { pertanian dengan pasar atau } \\
\text { agar para petani tidak } \\
\text { kesulitan menjual produk } \\
\text { mereka ke pasar. Atau BUM } \\
\text { Desa menjual jasa pelayanan } \\
\text { kepada warga dan usaha- }\end{array}$ & $\begin{array}{l}\text { - Jasa pembayaran listrik, } \\
\text { telepon dan air. } \\
\text { - Desa mendirikan pasar desa } \\
\text { untuk memasarkan produk- } \\
\text { produk yang dihasilkan di } \\
\text { masyarakat. BUM Desa } \\
\text { membangun jaringan dengan } \\
\text { swasta atau pasar yang lebih } \\
\text { luas guna memasarkan produk- }\end{array}$ \\
\hline
\end{tabular}




\begin{tabular}{|c|c|c|}
\hline & usaha masyarakat. & produk lokal \\
\hline Holding & $\begin{array}{l}\text { BUM Desa sebagai "usaha } \\
\text { bersama" atau sebagai induk } \\
\text { dari unit-unit usaha yang ada } \\
\text { di desa, dimana masing- } \\
\text { masing unit yang berdiri } \\
\text { sendiri-sendiri ini diatur dan } \\
\text { ditata sinerginya oleh BUM } \\
\text { Desa agar tumbuh usaha } \\
\text { bersama. }\end{array}$ & $\begin{array}{l}\text { - Usaha penyediaan kapal desa } \\
\text { yang berskala besar untuk } \\
\text { mengorganisir dan mewadahi } \\
\text { nelayan-nelayan kecil. } \\
\text { - "Desa Wisata" yang } \\
\text { mengorganisir bebagai jenis } \\
\text { usaha dari kelompok- } \\
\text { kelompok masyarakat, } \\
\text { makanan, kerajinan, sajian } \\
\text { wisata, kesenian, penginapan } \\
\text { dll. } \\
\text { Usaha supplier bahan baku } \\
\text { atau penampung produk yang } \\
\text { akan dipasarkan keluar desa. }\end{array}$ \\
\hline $\begin{array}{l}\text { Trading/ } \\
\text { Usaha } \\
\text { Perdagangan }\end{array}$ & $\begin{array}{l}\text { BUM Desa dapat mendirikan } \\
\text { toko/warung untuk } \\
\text { memperdagangkan } \\
\text { komoditas kebutuhan warga }\end{array}$ & $\begin{array}{l}\text { - Unit usaha Toko Saprotan } \\
\text { (Sarana Produksi Pertanian) } \\
\text { dan atau Toko Sembako }\end{array}$ \\
\hline $\begin{array}{l}\text { Contracting/ } \\
\text { Kontrak }\end{array}$ & $\begin{array}{l}\text { BUM Desa dapat melakukan } \\
\text { kontrak dengan pihak lain } \\
\text { untuk melaksanakan/ } \\
\text { memenuhi kebutuhan pihak } \\
\text { lain misalnya BUM desa } \\
\text { melakukan kontrak kerja } \\
\text { untuk memenuhi kebutuhan } \\
\text { tenaga pembersih (Cleaning } \\
\text { Service) yang dilakukan oleh } \\
\text { perusahaan/ instansi yang ada } \\
\text { di desa tersebut. }\end{array}$ & $\begin{array}{l}\text { - Unit usaha cleaning service } \\
\text { - Unit usaha sub kontraktor. } \\
\text { Untuk melaksanakan } \\
\text { pembangunan fisik skala kecil. }\end{array}$ \\
\hline
\end{tabular}


Sumber : Tabel tentang tipe usaha, deskripsi dan contoh usaha yang bersumber dari hasil penelitian FPPD-ACCESS 2010.

Selanjutnya dijabarkan secara rinci dalam Pasal 88 UU Nomor 6 Tahun 2014, menyebutkan bahwa:

1. Pendirian BUM Desa disepakati melalui Musyawarah Desa.

2. Pendirian BUM Desa sebagaimana dimaksud pada ayat (1) ditetapkan dengan Peraturan Desa.

Dalam Pasal 89 menyebutkan tentang Hasil Usaha BUM Desa dimanfaatkan untuk:

1. Pengembangan usaha; dan

2. Pembangunan desa, pemberdayaan masyarakat desa dan pemberian bantuan untuk masyarakat miskin melalui hibah, bantuan sosial dan kegiatan dana bergulir yang ditetapkan dalam Anggaran Pendapatan dan Belanja Desa.

Pasal 90 menyebutkan bahwa Pemerintah, Pemerintah Daerah Provinsi, Pemerintah Daerah Kabupaten/Kota, dan Pemerintah Desa mendorong perkembangan BUM Desa dengan:

1. Memberikan hibah dan/atau akses permodalan;

2. Melakukan pendampingan teknis dan akses ke pasar; dan

3. Memprioritaskan BUM Desa dalam pengelolaan sumber daya alam di Desa. ${ }^{1}$

Kelembagaan BUM Desa bersifat unik, karena BUM Desa bukan sebagai usaha murni pemerintah desa, bukan usaha kelompok, bukan pula usaha swasta. BUM Desa adalah usaha bersama antara pemerintah desa dan masyarakat. Tidak seperti Koperasi, CV dan PT yang badan hukumnya sudah ada, badan hukum BUM Desa belum ada namun badan hukum bisa mengikuti berdasarkan jenis usaha yang dijalankannya. Unit usaha yang dibentuk oleh BUM Desa dimungkinkan untuk menginduk pada payung hukum yang ada, misalnya unit

\footnotetext{
${ }^{1}$ Suharyanto, Hastowiyono, Pelembagaan BUM Desa, (Yogyakarta: Forum Pengembangan Pembaharuan Desa, 2014) hlm 4.
} 
usaha simpan pinjam yang dibentuk dalam BUM Desa harus tunduk pada Undang-Undang Nomor 1 Tentang LKM, dan pembentukannya wajib mendapatkan ijin dari OJK (Otoritas Jasa Keuangan) atau mengikuti aturan badan hukum koperasi.

Meskipun BUM Desa terpisah dari struktur formal pemerintahan desa, tetapi BUM Desa tidak berdiri secara ekslusif. Kebijakan pendirian BUM Desa harus melalui Peraturan Desa, yang disiapkan oleh Kepala Desa bersama BPD. Maka dalam konteks ini BPD juga berwenang melakukan pengawasan umum terhadap BUM Desa untuk menjaga agar BUM Desa berjalan secara akuntabel.

Untuk mengelola BUM Desa, pengurus harus paham prinsip-prinsip pengelolaannya dengan baik. Terdapat enam prinsip dalam mengelola BUM Desa yaitu:

a. Kooperatif, yaitu semua komponen yang terlibat di dalam BUM Desa harus mampumelakukan kerjasama yang baik demi pengembangan dan kelangsungan hidup usahanya.

b. Partisipatif, yaitu semua komponen yang terlibat di dalam BUM Desa harus bersedia secara sukarela atau diminta memberikan dukungan dan kontribusi yang dapat mendorong kemajuan usaha BUM Desa.

c. Emansipatif, yaitu semua komponen yang terlibat di dalam BUM Desa harus diperlakukan sama tanpa memandang golongan, suku, dan agama.

d. Transparan, yaitu aktivitas yang berpengaruh terhadap kepentingan masyarakat umum harus dapat diketahui oleh segenap lapisan masyarakat dengan mudah dan terbuka.

e. Akuntabel, yaitu seluruh kegiatan usaha harus dapat dipertanggungjawabkan secara teknis maupun administratif.

f. Sustainabel, yaitu kegiatan usaha harus dapat dikembangkan dan dilestarikan oleh masyarakat dalam wadah BUM Desa. ${ }^{2}$

\footnotetext{
${ }^{2}$ Suharyanto, Rossana Dewi, M Barori, Pengembangan dan Pengelolaan BUM Desa, (Yogyakarta: Forum Pengembangan Pembaharuan Desa, 2014) hlm. 26.
} 
Keterlibatan warga masyarakat mulai dari perencanaan, pelaksanaan kegiatan, monitoring hingga mengikuti laporan pertanggungjawaban pengurus diharapkan akan berimplikasi terhadap semangat untuk memajukan BUM Desa, sehingga aspek transparasi atau keterbukaan penting untuk dikedepankan.

Implementasi agenda BUM Desa sebagai ujung tombak pemakmuran masyarakat desa tidak selamanya dapat berjalan sesuai dengan tujuan-tujuan di atas, mengingat setiap desa memiliki karakteristik dan kompleksitasnya masingmasing. Hal ini tergambar melalui hasil penelitian yang dilaksanakan pada BUM Desa Petanahan Kecamatan Petanahan Kabupaten Kebumen. Terdapat beberapa problematika yang muncul dalam implementasinya untuk mengembangkan ekonomi masyarakat.

\section{METODE PENELITIAN}

Penelitian ini menggunakan metode deskriptif kualitatif yang fokus penelitian dilakukan untuk melihat Implementasi Badan Usaha Milik Desa (BUM Desa) Petanahan Kecamatan Petanahan Kabupaten Kebumen. Metode pengumpulan data dilakukan dengan melakukan observasi, wawancara mendalam dan studi dokumentasi.

\section{PEMBAHASAN}

\section{Pendirian}

Sejarah pendirian BUM Desa Petanahan berawal pada bulan Juni, tahun 2010, dan pada saat itu terdapat sekelompok mahasiswa UGM yang sedang melakukan KKN di Desa Petanahan dengan fokus kegiatan pemberdayaan lingkungan masyarakat melalui pengolahan kelapa terpadu. Pengolahan kelapa tersebut menjadi beberapa hasil produksi seperti VCO (Virgin Coconut Oil), air kelapa menjadi Nata De Coco, dan serabut kelapa menjadi Coco Fiber. Kegiatan pemberdayaan ini terbantu dengan adanya bantuan prolisis (mesin pengolah alat tempurung) dari Dinas Pertanian dan Perkebunan. Bantuan tersebut mensyaratkan penerima bantuan diharuskan berbadan hukum koperasi. Oleh karena itu, BUM Desa Petanahan pada masa-masa awalnya memiliki bentuk kelembagaan sebagai 
koperasi "Sun Coco".

Seluruh kegiatan produksi koperasi, baik VCO, Nata De Coco, atau pun Coco Fiber sepenuhnya dilakukan oleh masyarakat. Seluruh hasil dari kegiatan produksi pada waktu itu dibeli seluruhnya oleh Prof. Bambang Seno Aji, dosen pembimbing mahasiswa KKN yang sekaligus memiliki perusahaan pengolahan kelapa, PT. Tropica Nucifera. Namun pembelian hasil produksi yang dilakukan Prof. Bambang hanya berjalan selama enam bulan. Setelah itu, para pengrajin berada pada ambang kebangkrutan karena belum ada lagi calon pembeli yang mau membeli hasil produksi mereka.

Pada awal tahun 2011, BPTP (Balai Pengkajian Teknologi Pertanian) Provinsi bersama dengan Dinas Pertanian, melakukan penilaian terhadap usaha pengolahan kelapa terpadu di Desa Petanahan. Sesudahnya, BPTP dan Dinas Pertanian menawari Sun Coco untuk melakukan pendampingan dan melakukan musyawarah yang melibatkan para pengrajin untuk menentukan produk prioritas. Berdasarkan hasil musyawarah tersebut, terpilihlah Nata De Coco karena sudah tidak ada lagi pengrajin yang memproduksi VCO dan Coco Fiber. Tidak hanya mendapatkan pendampingan, Sun Coco juga mendapatkan fasilitasi yang mempertemukan para pengrajin dengan calon pembeli, yaitu PT. Tropica Semarang. Pertemuan tersebut menghasilkan kesepakatan bahwa PT. Tropica Semarang akan membeli hasil produksi Nata De Coco jika Sun Coco mampu memenuhi kuota produksi sebanyak dua ton dalam batas waktu yang ditentukan. Ketika tiba batas waktu tersebut, ternyata Sun Coco hanya mampu memenuhi kuota dua kuintal. Oleh karena itu PT.Tropica Semarang memutus hubungan kerjasamanya tanpa mengambil hasil produksi nata de coco sebanyak dua kuintal tersebut.

Dihadapkan pada potensi kerugian sebanyak dua kuintal nata de coco, pengelola Sun Coco mencari-cari sendiri pembeli, hingga mendapatkan kesepakatan dengan pembeli dari jogja. Kemampuan produksi Sun Coco yang hanya dapat membuat satu kuintal nata de coco per minggu, perlahan-lahan meningkat, hingga per awal tahun 2016, kemampuan produksinya mencapai tiga sampai empat ton per minggu. 
Setelah permasalahan nata de coco terselesaikan, pengelola memutar otak untuk mencari solusi bagi unit usaha VCO yang mangkrak. Beruntung Prof. Bambang mengutus salah satu quality control perusahaannya untuk mencari VCO sebagai bahan baku minyak goreng. Pihak pengelola pun memanfaatkan kesempatan ini untuk meminta diajarkan cara membuat minyak goreng, yang akhirnya disetujui dan direalisasikan melalui pelatihan dengan menggunakan anggaran dari BPTP dan Dinas Pertanian. Menjelang akhir tahun 2011, wacana untuk mengubah Sun Coco dari koperasi menjadi BUM Desa muncul di kalangan pengelola. Munculnya wacana ini didasari pada beberapa alasan yang disampaikan pengelola BUM Desa Petanahan yaitu: a) untuk pengamanan asset; b) penyumbang untuk PADes; c) dari sisi pengawasan lebih mudah; d) pengadministrasian tidak serumit kalau koperasi karena di Koperasi ada simpanan pokok, simpanan wajib.

Pengamanan aset menjadi isu krusial dalam pengelolaan BUM Desa akibat buruknya citra koperasi yang disebabkan aset-aset koperasi dikelola dan menjadi hak milik pengrajin. Oleh karena itu, jika kelompok yang mendapatkan bantuan sudah tidak lagi berjalan, maka banyak aset-aset produksi yang hilang. Berbeda dengan BUM Desa yang seluruh kepemilikan asetnya atas nama lembaga.

Pengalihan status Sun Coco dari koperasi menjadi BUM Desa Petanahan baru terlaksana pada tahun 2012, setelah para pengelola koperasi mendapatkan undangan dari Bapermades untuk mengikuti pelatihan pengelolaan BUM Desa yang diselenggarakan oleh BPMD Yogyakarta. Pelatihan tersebut ditindaklanjuti dengan menggelar musyawarah yang dihadiri oleh seluruh unsur BPD, perangkat desa, dan pengurus Sun Coco, guna membahas pembentukan BUM Desa. Pembentukan BUM Desa ini ditetapkan dalam Perdes No. 1 tahun 2012.

\section{Pengelolaan dan Pengembangan BUM Desa}

Penetapan BUM Desa Petanahan pada tahun 2012 tidak diikuti dengan perumusan AD/ART dan restrukturasi organisasi BUM Desa. Oleh karena itu, struktur kepengurusan BUM Desa masih menggunakan struktur lama sewaktu masih berbadan hukum koperasi, di mana mayoritas anggotanya berasal dari BPD 
dan perangkat desa. Struktur kepengurusan BUM Desa Petanahan terdiri dari komisaris (dijabat oleh kepala desa secara ex officio), manager (ketua BUM Desa), bendahara, sekretaris, dan pembantu.

Menurut pelaksana operasional BUM Desa, kepala desa hanya sesekali datang berkunjung tanpa memberikan arahan apapun terhadap BUM Desa. Sama halnya dengan kepala desa, BPD yang seharusnya mengawasi pengelolaan BUM Desa juga belum melakukan tugas sebagaimana mestinya. Masih berdasarkan keterangan pelaksana operasional BUM Desa, memang anggota BPD beberapa kali datang meninjau proses produksi, tetapi sama sekali tidak melontarkan pertanyaan terkait produksi dan pengelolaan.

\section{Kerjasama}

BUM Desa Petanahan tidak hanya memproduksi serta menjual hasil olahan kelapa para pengrajin yang berdomisili di Desa Petanahan saja. Tetapi juga menjalin kerjasama dengan kelompok-kelompok yang terdapat di sekitar Desa Petanahan dalam hal pemasaran hasil produksi. Sebagai contoh, pengrajin gula semut dari desa tetangga dapat menitipkan hasil produksinya ke BUM Desa. BUM Desa kemudian membantu menjual hasil produksi tersebut kepada para pembeli di Probolinggo.

Selain dengan kelompok pengrajin gula semut, BUM Desa Petanahan juga menjalin kerjasama pemasaran dengan para pengrajin ceriping, kelompok pembuat lanting, dan kelompok-kelopok pembuat makanan lainnya. Kerjasama antara BUM Desa Petanahan dengan para pengrajin dilakukan berdasarkan kepercayaan, oleh karena itu tidak ada prosedur-prosedur administrasi yang harus dilalui dalam pelaksanaan kerjasama tersebut. Meskipun begitu, keuntungan yang dapat diraih BUM Desa Petanahan melalui kerjasama pemasaran produk ini sangat kecil, sehingga belum dapat memberikan penambahan signifikan pada kas BUM Desa.

\section{Peran Pemerintah Provinsi dan Kabupaten}

Pengembangan usaha pengolahan kelapa terpadu yang dilakukan BUM Desa Petanahan mendapatkan banyak dukungan dari pemerintahan kabupaten dan 
provinsi. Sejumlah bantuan justru mengalir deras dari lembaga-lembaga selain Bapermades. Pengelola BUM Desa Petanahan menjelaskan:

"Dari Balitbang Provinsi, kemudian dari Dinas Koperasi dan UMKM Provinsi dan Kabupaten, termasuk kita difasilitasi sertifikat Halal dari Dinas KUMKM, terus PIRT dari Disperindag, terus pameran dan sebagainya dari Disperindag, terus kemudian Dinas KUMKM, mungkin juga Pemda Sekda, ketika mereka punya event-event itu kita produknya ikut kesana ..... Balitbang juga masih, itu dalam bentuk: pertama, pendukung kapasitas produksi, melalui penanaman awal, pendukung kualitas produksi melalui alat-alat yang meningkatkan kualitas produksi contoh yang Balitbang, contohnya itu dulu kita pernah memasarkan minyak goreng, dikomplain sama pembeli karena penga (bau) dan sebagainya. Misalnya kita cari solusi itu, bentuknya adalah mesin Vacuum Evaluator, dari Balitbang diberi itu, Alhamdulillah sampai sekarang juga sangat bermanfaat."

Banyaknya bantuan yang diberikan oleh pemerintah provinsi dan kabupaten kepada BUM Desa Petanahan rata-rata terfokus pada keperluan produksi, mulai dari modal hingga peralatan. Namun seluruh bantuan tersebut tidak dapat dimanfaatkan secara maksimal untuk menghindari kerugian akibat oversupply karena BUM Desa Petanahan belum memiliki pembeli tetap.

\section{Hasil Produk BUM Desa Petanahan}

BUM Desa Petanahan memiliki beberapa jenis produk yang dipasarkan, yakni VCO, HCO, minyak goreng klentik, dan nata de coco. Masing-masing produk tersebut memiliki alur produksi dan pemasaran tersendiri.

\section{VCO (Virgin Coconut Oil)}

VCO adalah salah satu produk unggulan BUM Desa Petanahan. Dalam alur produksi VCO, BUM Desa Petanahan berperan sebagai pengepul hasil produksi para pengrajin. Pada umumnya, para pengrajin menjual VCO hasil produksi mereka 
dalam bentuk jerigen, dengan kualitas minyak yang masih kasar, keruh, dan kotor. Setiap kilogram VCO yang disetorkan oleh pengrajin kepada BUM Desa dihargai Rp 30.000. VCO yang masih keruh tersebut kemudian diolah kembali oleh BUM Desa, disaring sebanyak minimal 30 kali. Jumlah ini masih jauh jika dibandingkan jumlah minimal penyaringan yang disarankan pada saat pelatihan-pelatihan. Hanya saja, menurut pelaksana operasional BUM Desa, jumlah 30 kali penyaringan sudah cukup untuk memberikan hasil VCO yang memenuhi kebutuhan pasar.

Setelah disaring sebanyak 30 kali, VCO didiamkan di dalam toples dan dikocok sebanyak 30 kali, lalu didiamkan di dalam toples selama 8-10 jam guna memisahkan VCO dari blendo.Waktu terbaik untuk memisahkan VCO adalah setelah didiamkan selama 8-10 jam, karena jika didiamkan selama 8-10 jam, VCO akan berada pada bagian atas, sedangkan jika lebih dari 10 jam, VCO akan berada pada bagian tengah toples, sehingga akan lebih sulit untuk dipisahkan. Pemisahan VCO dilakukan dengan menggunakan sendok sayur yang sudah dibalut menggunakan kain agar, sehingga dapat sekaligus menyaring blendo yang mungkin ikut terambil.

Kelapa yang dapat diolah untuk membuat VCO memiliki kriteria tersendiri, yaitu kelapa kiring (buah kelapa yang sudah berumur sangat tua) yang sudah didiamkan selama minimal tiga hari. Harga kelapa kiring berkisar mulai dari $\mathrm{Rp} 1.800$ per butir kelapa kecil dan Rp 3.500 per butir kelapa besar. Persyaratan mendiamkan kelapa selama tiga hari terkadang disiasati oleh para pengrajin untuk mempersingkat waktu tunggu yang dibutuhkan.

Minyak dari kelapa yang tanpa didiamkan terlebih dahulu sebelum diolah dapat merugikan BUM Desa Petanahan. Hal ini disebabkan kualitas minyak dari kelapa yang langsung diolah masih jauh dari ekspektasi pasar, sehingga memiliki potensi besar 
untuk ditolak oleh pembeli, dan pada akhirnya menuntun BUM Desa pada kerugian. VCO hasil penyaringan BUM Desa biasanya dibeli oleh eksportir individu utuk dikirim ke luar negeri, dengan harga Rp 40.000 per kilogram. Selain itu terdapat juga pembeli eceran, baik yang berasal dari sekitar Desa Petanahan, seperti Karanganyar, Kebumen, Rowokele, dan Rs. PKU Muhammadiyah ataupun lain provinsi, seperti Bogor dan Bali. Harga jual VCO eceran lebih mahal $\mathrm{Rp} 10.000$ daripada harga yang dijual secara grosir.

\section{HCO (Health Coconut Oil)}

BUM Desa Petanahan pernah membuat HCO (Health Coconut Oil) untuk menyiasati kerugian karena VCO yang diproduksi tidak dapat memenuhi kualitas yang ditetapkan oleh pasar. HCO merupakan produk dari hasil konversi VCO yang sudah rusak akibat terlalu lama ditimbun karena tidak laku, menjadi minyak goreng putih dengan harga $\mathrm{Rp} 40.000$ per kilogram.

Pada waktu itu, HCO dijual dalam jumlah besar oleh sebuah toserba di Kebumen. Tetapi meskipun permintaan pasar atas HCO di Kebumen cukup tinggi, BUM Desa Petanahan tidak dapat memenuhi permintaan tersebut karena pada dasarnya memang tidak mengkhususkan HCO sebagai salah satu produk unggulan BUM Desa. Hal ini disebabkan jika dihitung untungruginya, harga jual HCO hanya Rp 40.000, sedangkan harga jual VCO yang belum diolah saja sudah mencapai Rp 40.000 jika dijual secara grosir, dan Rp 50.000 jika dijual secara eceran. Padahal pembuatan HCO melalui proses yang lebih panjang daripada VCO.

\section{Minyak Klentik}

Klentik adalah minyak goreng yang terbuat dari blendo, yaitu ampas dari hasil santan yang dikocok dan didiamkan selama 8-10 jam hingga menghasilkan VCO. Blendo kemudian direbus 
hingga mengeluarkan minyak berwarna kuning. Minyak klentik yang belum melalui proses pengolahan lebih lanjut, dihargai $\mathrm{Rp}$ 10.000 per kilogram, sedangkan minyak yang sudah melalui proses pemisahan dari lilin dan kotoran, dihargai Rp 17.000 per kilogram. Proses pemisahan kotoran ini hanya bisa dilakukan oleh BUM Desa karena harus menggunakan mesin listrik. Penjualan minyak klentik oleh BUM Desa Petanahan dilakukan dalam skala lokal desa, dengan cara menjual minyak-minyak tersebut ke individuindividu yang ingin membeli langsung ke BUM Desa, serta menitipkan ke warung-warung tradisional untuk dijual.

\section{Nata De Coco}

Selain VCO dan turunannya, BUM Desa Petanahan juga memproduksi nata de coco. Setiap minggunya, BUM Desa Petanahan dapat memproduksi 3-4 ton nata de coco, tergantung dari ketersediaan jumlah air kelapa di Petanahan. Hasil produksi nata de coco dijual ke perusahaan pemotongan nata de coco di Bantul dengan harga jual Rp 1.250 per kilogram. BUM Desa Petanahan belum dapat menjual langsung ke pabrik produsen makanan atau konsumen karena nata de coco yang diproduksi masih berupa balok-balok padat seberat 1,25 hingga 1,5 kilogram.

Banyaknya jenis produk yang diproduksi BUM Desa Petanahan berimbas pada pencemaran lingkungan. Aduan yang disampaikan masyarakat pada umumnya tentang pembuangan limbah yang dilakukan oleh beberapa pengrajin ke dalam lubang galian yang dibuat seadanya, sehingga air limbah mencemari sumur tetangga pengrajin-pengrajin tersebut. Oleh karena itu, BUM Desa Petanahan mengarahkan para pengrajinnya untuk membuang limbah ke tempat pembuangan yang dibangun secara permanen, seperti septic tank, sehingga tidak lagi mencemari sumur tetangga mereka. 


\section{Implementasi BUM Desa Petanahan dalam Pengembangan Ekonomi Masyarakat}

Keberadaan BUM Desa merupakan salah satu upaya konkret dalam mewujudkan otonomi desa yang sesuai dengan amanah Undang-Undang Pemerintah Daerah. Pemerintah Desa dapat mengelola aset-aset dan potensi desa dengan kreatif, inovatif dan mandiri melalui kepemilikan BUM Desa, sehingga dapat menciptakan lapangan pekerjaan baru di desa serta memberikan pelayanan yang optimal bagi masyarakat dalam mengakses modal kerja.

Badan Usaha Milik Desa diharapkan dapat mampu meningkatkan sumber pendapatan desa untuk pembangunan. BUM Desa sebagai salah satu lembaga ekonomi yang beroperasi di pedesaan, memiliki perbedaan dengan lembaga ekonomi pada umumnya (Koperasi, PT, LKM, CV dll). Hal ini dimaksudkan agar keberadaan dan kinerja BUM Desa mampu memberikan kontribusi yang signifikan terhadap peningkatan Anggaran Pendapatan dan Belanja Desa (APB Desa) yang mampu mensejahterakan warga desa, dapat menekan berkembangnya sistem usaha kapitalistis di pedesaan yang dapat mengakibatkan terganggunya nilai-nilai kehidupan bermasyarakat.

Kehadiran BUM Desa Petanahan, di satu sisi menciptakan lapangan pekerjaan bagi masyarakat Desa Petanahan, tetapi di sisi lain, belum dapat memberikan banyak kontribusi terhadap perekonomian masyarakat. Pada masa-masa awal dibentuknya BUM Desa, jumlah pengrajin yang merupakan masyarakat Desa Petanahan mencapai 30 orang. Namun kini, jumlah tersebut terkoreksi secara signifikan hingga tinggal tersisa tiga orang. Menurut pelaksana operasional BUM Desa:

"Karena yang lain itu penghasilannya daripada membuat itu, mungkin lebih banyak dari usaha lain. Di buat sampingan juga susah kalau seperti ini, malam biasanya sudah capek karena siangnya bekerja. Di sini kan kebanyakan masyarakatnya bekerja semua, kebanyakan berdagang. Jadi hasilnya itu lebih banyak berdagang. Kalau dibuat sampingan tidak ada waktunya, kalau bekerja (rutin seperti kantoran) 
kan jelas ada waktunya, kalau berdagang tidak memakai waktu, pagi sampai sore biasanya."

Berdasarkan keterangan di atas, terlihat bahwa alasan berkurangnya jumlah pengrajin yang ikut terlibat dalam BUM Desa Petanahan disebabkan penghasilan masyarakat yang mayoritas memiliki mata pencaharian sebagai pedagang masih lebih tinggi daripada menjadi pengrajin VCO ataupun nata de coco, sedangkan masyarakat yang tergolong miskin dan tidak memiliki usaha lebih memilih untuk bekerja serabutan. Mereka beralasan bahwa lebih baik bekerja serabutan daripada membuat VCO atau nata de coco karena proses pembuatan kedua produk tersebut tergolong sulit, selain itu juga malu jika tidak bisa mengembalikan hutang apabila dihutangi air kelapa sebagai bahan baku produksi oleh BUM Desa.

Hal ini juga terjadi karena dalam pengelolaan BUM Desa yang tidak fokus maka untuk melakukan inovasi dan pengembangan cenderung lemah, bahkan untuk pengelola, pengawas ataupun petugas operasional tidak mendapat penghasilan yang tetap (untuk operator dibayar hanya ketika ada yang setor, itu dalam seminggu hanya 2 kali). Sedangkan untuk yang lainnya hanya diberikan setiap tahun (THR) saat lebaran. Mungkin ini juga yang menjadi kendala berkembangnya pengelolaan BUM Desa ini.

Pendirian dan pengembangan BUM Desa hanya akan terjadi jika para pendiri "berani memiliki impian". Para pendiri BUM Desa harus berani berpikir besar (think big) dengan membangun visi dari BUM Desa. Visi dari BUM Desa inilah yang akan menjadi energi penggerak agar para pendiri dan pengelola berani untuk segera memulai. ${ }^{3}$

\section{KESIMPULAN}

\footnotetext{
${ }^{3}$ Sukasmanto, Rancang Bangun Bisnis dan Pengelolaan BUM Desa, (Yogyakarta: Forum Pengembangan Pembaharuan Desa, 2014) hlm. 3.
} 
BUM Desa Petanahan belum memberikan dampak peningkatan ekonomi terhadap masyarakat desa. Bahkan kondisinya seolah-olah "hidup segan mati tak mau" karena prioritasnya hanya barang terjual, belum pada pengembangan usaha yang utamanya dapat meningkatkan pendapatan ekonomi masyarakat Desa Petanahan khususnya. Karena di Petanahan terdapat hampir 100 unit UKM dengan berbagai macam usaha yang mayoritas dibidang olahan makanan. Menurut para pelaku UKM selama ini BUM Desa belum pernah memberikan kontribusi bagi mereka, karena selama ini BUM Desa hanya fokus pada pengolahan minyak VCO dan Nata De Coco.

Para pelaku UKM ini banyak terkendala pada permodalan dan pemasaran. Karena selama ini hasil produksinya dijual di Pasar dan bos pasar hanya mau menampung barang dan akan dibayar setelah laku terjual sisanya kembali ke pengrajin (untuk olahan makanan basah akan sangat dirugikan jika tidak terjual habis). Mata rantai pemasaran cukup panjang sehingga laba yang diperoleh sedikit, dan resiko menanggung kerugian lebih besar. Karena belum ada lembaga yang menangani perlindungan produsen (sering menanggung kerugian). Masih sangat sedikit pengrajin yang membentuk kelompok, padahal dengan adanya kelompok lebih mudah mengakses bantuan yang ada dari pemerintah.

Pemerintah Kabupaten dan propinsi juga belum sepenuhnya hadir untuk membina, selama ini hanya baru pada promosi produk (dalam even-even tertentu), pelatihan dan bantuan alat. Untuk akses pemasaran dan pengembangan usaha dengan memanfaatkan potensi SDA dan SDM belum dilakukan. Yang akhirnya kehadiran BUM Desa justru tidak memberikan manfaat ekonomi bagi masyarakat lokal. Selain itu ditingkat Kabupaten belum ada regulasi yang mengatur secara khusus terkait BUM Desa sehingga desa masih merasa ragu untuk melakukan pengembangan usaha.

\section{DAFTAR PUSTAKA}

Suharyanto, Hastowiyono. 2014. Pelembagaan BUM Desa. Yogyakarta: Forum 
Pengembangan Pembaharuan Desa.

Suharyanto, Rossana Dewi dan M Barori. 2014. Pengembangan dan Pengelolaan BUM Desa. Yogyakarta: Forum Pengembangan Pembaharuan Desa.

Sukasmanto. 2014. Rancang Bangun Bisnis dan Pengelolaan BUM Desa. Yogyakarta: Forum Pengembangan Pembaharuan Desa.

Undang-Undang RI Nomor 6 Tahun 2014 dan Peraturan Pemerintah RI Tahun 2016 Tentang Desa. 2016. Bandung: Citra Umbara. 